\title{
Utilitas Asam Organik Sari Belimbing Wuluh dan Asam Sitrat Sintetis Sebagai Acidifier Terhadap Performa Produksi Puyuh (Coturnix coturnix Japonica) Fase Grower
}

\author{
Hamdan Has, Astriana Napirah, Widhi Kurniawan, La Ode Nafiu, Takdir Saili \\ Jurusan Peternakan, Fakultas Peternakan, Universitas Halu Oleo \\ Jl. H.E.A. Mokodompit Kampus Hijau Bumi Tridharma, Anduonohu, Kendari 93232 \\ Email korespondensi: hamdan_has@uho.ac.id
}

(Diterima 18-02-2020; disetujui 08-05-2020)

\begin{abstract}
ABSTRAK
Penggunaan acidifier baik organik atau sintetis dapat meningkatkan optimalisasi nutrien di dalam saluran pencernaan. Optimalisasi nutrien diharapkan dapat meningkatkan performa ternak khususnya puyuh. Penelitian ini bertujuan untuk mengetahui pengaruh penggunaan dua macam acidifier terhadap performa puyuh fase grower. 100 ekor unsexed puyuh (Coturnix coturnix Japonica) fase grower umur 14-40 hari digunakan dalam penelitian yang menggunakan rancangan acak lengkap dengan lima perlakuan dan empat ulangan. Bahan pakan yang digunakan adalah jagung kuning, dedak, konsentrat puyuh komersil, sari belimbing wuluh, dan asam sitrat sintetis. Perlakuan yang dicobakan terdiri dari perlakuan kontrol (P0), penggunaan 0,3\% asam sitrat sintetis (P1), penggunaan $0,25 \%$ sari belimbing wuluh (P2), penggunaan $0,6 \%$ asam sitrat sintetis $(\mathrm{P} 3)$, dan penggunaan $0,5 \%$ sari belimbing wuluh (P4). Variabel yang diamati adalah konsumsi ransum, pertambahan bobot badan dan konversi ransum mingguan. Penggunaan sari belimbing wuluh memiliki konsumsi pakan yang lebih rendah $(\mathrm{P}<0,05)$ pada minggu pertama dibanding kontrol dan asam sitrat sintetis. Penggunaan asam sitrat sintetis meningkatkan pertambahan bobot badan pada minggu pertama $(\mathrm{P}<0,05)$. Penggunaan asam sitrat sintetis nyata dapat menurunkan konversi pakan minggu ke tiga dan empat dibanding kontrol dan asam organik belimbing wuluh. Kesimpulan penelitian ini yaitu penggunaan sari belimbing wuluh sebagai acidifier belum menunjukkan perbaikan performa yang signifikan sedangkan penggunaan asam sitrat sintetis memiliki performa yang lebih baik dibanding perlakuan kontrol dan penggunaan sari belimbing wuluh.
\end{abstract}

Kata kunci: acidifier, asam sitrat, belimbing wuluh, puyuh fase grower

\begin{abstract}
The organic and synthetic acidifiers could improve the optimization of nutrients utilization in the quail digestive tract. Furthermore, the optimization of nutrients is expected to improv quail performance. This study was aimed to determine the effect of using two types of acidifiers (Averrhoa bilimbi juice and synthetic citric acid) on the grower phase of quail performance. Total of 100 unsexed quails (Coturnix coturnix japonica) grower phase aged 14-40 days were used in this research and designed as completely randomized design of five treatments and four replications. Feed ingredients used were yellow corn, rice bran, commercial quail concentrate, Averrhoa bilimbi juice (organic acidifier), and synthetic citric acid. The treatments consisted of control (P0), $0.3 \%$ synthetic citric acid (P1), use of $0.25 \%$ Averrhoa bilimbi juice (P2), use of $0.6 \%$ synthetic citric acid (P3), and use of $0.5 \%$ Averrhoa bilimbi juice (P4). The variables observed were weekly feed intake, body weight gain, and feed conversion. The result showed that utilization of Averrhoa bilimbi juice has lower feed consumption $(\mathrm{P}<0.05)$ in the first week compare to control and synthetic citric acid, and synthetic citric acid utilization increases body weight gain in the first week $(\mathrm{P}<0.05)$. The use of synthetic citric acid significantly reduces feed conversion in the third and fourth weeks compared to control and organic acid groups. The conclusion of this study is the utilization of Averrhoa bilimbi juice as an acidifier has not shown significant improvements in quail performance. The use of synthetic citric acid has a better performance compared to control and Averrhoa bilimbi juice utilization.
\end{abstract}

Keywords: acidifier, organic acidifier, citric acid, growing quail 


\section{PENDAHULUAN}

Puyuh merupakan salah satu ternak unggas yang sedang marak dikembang biakkan. Ternak ini memiliki waktu kematangan reproduksi yang lebih cepat dibanding unggas lainnya serta memiliki produksi telur yang tinggi. Selain sebagai penghasil telur, puyuh juga dapat dijadikan sebagai alternatif unggas pedaging. Puyuh pedaging umumnya diperoleh dari puyuh afkir atau puyuh yang masih dalam fase grower. Pengembangan puyuh fase grower umumnya hanya memperhatikan perkembangan jaringan otot dan pertambahan bobot badan, sehingga untuk memperoleh performa yang baik maka diperlukan pakan berkualitas dan tentunya efisien untuk mengejar nilai ekonomi yang lebih baik.

Dalam rangka memaksimalkan efisiensi pakan, maka perlu dilakukan optimalisasi penyerapan zat makanan. Ada beberapa cara yang dapat ditempuh untuk mengoptimalkan efisiensi penyerapan zat makanan di dalam saluran pencernaan, salah satunya dengan memanfaatkan acidifier. Acidifier adalah aditif pakan berupa asam organik yang dapat diberikan melalui pakan atau air minum. Pengasaman pakan dengan asam organik dilaporkan dapat menurunkan bakteri pathogen dan rancun metabolit, meningkatkan kecernaan protein, kalsium, phospor, magnesium, dan sebagai substrat dalam proses metabolisme (Veeramani et al., 2003). Penambahan asam organik dapat menjaga keseimbangan mikrobia dalam saluran pencernaan dengan cara mempertahankan $\mathrm{pH}$ saluran pencernaan, sehingga meningkatkan penyerapan protein dan massa protein daging (Natsir, 2007; Santia, 2009). Penggunaan asam juga dilaporkan dapat melakukan proteksi dari bakteri salmonella dan bakteri merugikan lainnya (Hamed \& Hasan, 2013).

Penggunaan acidifier pada unggas dapat diberikan dalam bentuk asam organik dan asam anorganik. Salah satu jenis asam yang biasa digunakan sebagai acdifier adalah asam sitrat. Asam sitrat mengasamkan saluran pencernaan sehingga menurunkan $\mathrm{pH}$, mempengaruhi laju digesta dan mengurangi populasi bakteri patogen yang berdampak positif terhadap kesehatan saluran pencernaan dan peningkatan kecernaan nutrien.
Asam sitrat dapat diperoleh di pasaran dalam bentuk produk yang dipatenkan (sintetis) atau dapat diperoleh dari bahan alami seperti yang banyak terdapat pada sari belimbing wuluh. Penggunaan acidifier pada puyuh fase grower diharapkan dapat meningkatkan optimalisasi pakan sehingga dapat diperoleh performa yang tinggi tetapi dengan pakan yang efisien. Guna melihat pengaruh penambahan asam sitrat dalam pakan ternak puyuh fase grower, baik dalam bentuk asam sitrat sintetis maupun asam sitrat alami, maka dilakukanlah peneltian ini.

\section{MATERI DAN METODE}

Penelitian ini menggunakan rancangan acak lengkap dengan 5 perlakuan dan 4 ulangan. Sebanyak 100 ekor puyuh unsexed umur dua minggu dengan berat berkisar antara 40-50 g digunakan dalam penelitian ini. Bahan pakan berupa jagung, dedak, konsentrat layer, asam sitrat dan sari belimbing wuluh juga digunakan sebagai materi dalam penelitian ini. Asam sitrat yang digunakan adalah asam sitrat sintetis berbentuk kristal yang banyak beredar di pasaran sedangkan asam sitrat organik diperoleh dari belimbing wuluh yang masih segar berwarna hijau muda dan banyak mengandung air.

Sari belimbing wuluh diperoleh dengan cara diblender tanpa tambahan air kemudian disaring menggunakan penyaring hingga yang tersisa hanya sari tanpa ampas. Pemberian asam sitrat sintetis dilakukan melalui pencampuran dalam ransum sedangkan sari belimbing wuluh diberikan melalui air minum.

Perlakuan yang digunakan sebagai berikut:

\section{P0: Kontrol}

$\mathrm{P} 1$ : Penggunaan $0,3 \%$ asam sitrat sintetis

P2: Penggunaan $0,25 \%$ sari belimbing wuluh

P3: Penggunaan $0,6 \%$ asam sitrat sintetis

P4: Penggunaan 0,5\% sari belimbing wuluh

Variabel yang diamati adalah konsumsi ransum, pertambahan bobot badan dan konversi ransum mingguan. Data yang diperoleh dianalisis menggunakan analisis ragam dan dilanjutkan menggunakan uji beda nyata terkecil dengan bantuan software SPSS versi 16.

Tabel 1. Komposisi dan Kandungan Nutrien Ransum Perlakuan

\begin{tabular}{lcccccc}
\hline Bahan Pakan & \multicolumn{9}{c}{ Kandungan nutrien } & Ca $(\%)$ & $\mathrm{P}(\%)$ \\
\cline { 2 - 7 } & Komposisi & EM $(\mathrm{kkal} / \mathrm{kg})$ & $\mathrm{PK}(\%)$ & $\mathrm{SK}(\%)$ & $\mathrm{Ca}$ & 0,03 \\
Jagung & 34 & 1132,2 & 2,8 & 1,2 & 0,06 & 0,05 \\
Dedak & 24 & 456 & 3,09 & 2,7 & 0,01 & 0,1 \\
Konsentrat & 42 & 1386 & 14,28 & 3,3 & 4,2 & 0,18 \\
\hline Jumlah & 100 & 2974,2 & 20,17 & 7,2 & 4,27 & 0
\end{tabular}

Keterangan: EM (energi metabolis), PK (protein kasar), SK (serat kasar), Ca (kalsium), P (fosfor) 


\section{HASIL DAN PEMBAHASAN}

\section{Konsumsi Ransum}

Penggunaan asam sebagai acidifier memberikan pengaruh nyata $(\mathrm{P}<0,05)$ terhadap konsumsi ransum. Penggunaan asam organik dari sari belimbing wuluh memiliki konsumsi pakan yang lebih rendah dibanding kontrol dan perlakuan asam sitrat sintetis pada minggu pertama tetapi cenderung tidak ada perbedaan pada minggu ke-2 hingga ke-4 dibanding kontrol. Penggunaan asam sitrat sintetis cenderung menurunkan konsumsi pakan $(\mathrm{P}<0,05)$ dibanding perlakuan lainnya terutama pada minggu ke-2 hingga ke-4.

Peningkatan level penggunaan asam, baik asam organik belimbing wuluh ataupun asam sitrat sintetis belum dapat mempengaruhi konsumsi ransum. Yosef et al. (2013) melaporkan bahwa puyuh fase grower yang diberi acidifier berupa asam asetat memiliki konsumsi pakan yang lebih rendah, bobot badan yang lebih tinggi serta konversi pakan yang lebih rendah dibanding tanpa pemberian asam. Byrd et al. (2001) melaporkan bahwa pemberian asam organik sebesar $0,5 \%$ asam asetat, $0,5 \%$ asam laktat atau $0,5 \%$ asam format dalam air minum dapat menurunkan jumlah bakteri pathogen (Salmonella dan Campylobacter) sehingga mempengaruhi mikroflora dalam saluran pencernaan.

\section{Pertambahan Bobot Badan}

Penggunaan asam organik belimbing wuluh secara nyata meningkatkan $(\mathrm{P}<0,05)$ pertambahan bobot badan pada minggu pertama tetapi menurunkan pertambahan bobot badan $(\mathrm{P}<0,05)$ pada minggu kedua. Sementara itu, penggunaan asam organik belimbing wuluh pada minggu ketiga dan keempat relatif sama dengan kontrol dan asam sitrat sintetis. Pertambahan bobot badan sangat dipengaruhi oleh konsumsi pakan dan optimalisasi penyerapan nutrien pada saluran pencernaan. Pio $e t$ al. (2017) melaporkan bahwa penggunaan asam organik dan asam anorganik sebagai acidifier dapat mempengaruhi histomorfometri duodenum pada ayam yang berperan dalam penyerapan nutrien. Pemberian acidifier pada ternak bertujuan untuk menurunkan $\mathrm{pH}$ saluran pencernaan dan menghambat perkembangan cytoplasma mikroba patogen pada usus halus, penghambatan tersebut menyebabkan pengurangan persaingan perebutan nutrien saluran pencernaan dan menhasilkan performa yang lebih baik (Gunal et al., 2006; Ghazalah et al., 2011)

Hasil ini tidak sesuai dengan yang dilaporkan oleh Natsir et al. (2007) bahwa penambahan asam sitrat dan asam laktat belum mampu merubah $\mathrm{pH}$ saluran pencernaan sehingga tidak berpengaruh terhadap kecernaan pakan. Hal serupa juga dilaporkan oleh Hidayat et al. (2018) bahwa pemberian asam organik dari perasan jeruk nipis belum dapat meningkatkan performa ayam pedaging tetapi dapat mempengaruhi populasi bakteri asam laktat dalam saluran pencernaan.

Tabel 2. Utilitas sari belimbing wuluh dan asam sitrat sintetis sebagai acidifier terhadap performa puyuh fase grower

\begin{tabular}{|c|c|c|c|c|}
\hline Parameter/perlakuan & Minggu 1 & Minggu 2 & Minggu 3 & Minggu 4 \\
\hline Konsumsi Ransum & \multicolumn{4}{|c|}{ 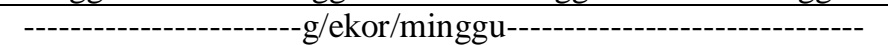 } \\
\hline P0 & $123,5^{\mathrm{b}} \pm 2,6$ & $148,8^{\mathrm{b}} \pm 8,1$ & $156,2^{\mathrm{b}} \pm 2,1$ & $172,4^{\mathrm{c}} \pm 1,5$ \\
\hline P1 & $124,4^{\mathrm{b}} \pm 3,6$ & $136,0^{\mathrm{a}} \pm 1,5$ & $134,4^{\mathrm{a}} \pm 1,6$ & $135,9^{\mathrm{a}} \pm 1,1$ \\
\hline $\mathrm{P} 2$ & $113,5^{\mathrm{a}} \pm 2,9$ & $146,5^{\mathrm{b}} \pm 4,9$ & $154,3^{\mathrm{b}} \pm 2,3$ & $166,0^{\mathrm{b}} \pm 1,9$ \\
\hline $\mathrm{P} 3$ & $130,7^{\mathrm{c}} \pm 3,5$ & $135^{\mathrm{a}}, 4 \pm 1$ & $130,9^{\mathrm{a}} \pm 1,8$ & $135,9^{\mathrm{a}} \pm 0,9$ \\
\hline P4 & $118,1^{\mathrm{a}} \pm 4,1$ & $144,2^{\mathrm{b}} \pm 5,7$ & $156,9^{\mathrm{b}} \pm 5,1$ & $165,8^{\mathrm{b}} \pm 5,4$ \\
\hline Pertambahan bobot badan & \multicolumn{4}{|c|}{-------------------------g/ekor/minggu---------------------------- } \\
\hline $\mathrm{P} 0$ & $27,0^{\mathrm{a}} \pm 2$ & $32,5^{\mathrm{b}} \pm 2,6$ & $29,2 \pm 4,8$ & $21,9 \pm 3,1$ \\
\hline P1 & $26,7^{\mathrm{a}} \pm 0,4$ & $31,7^{\mathrm{b}} \pm 1,3$ & $27,5 \pm 2,6$ & $23,0 \pm 1,4$ \\
\hline $\mathrm{P} 2$ & $30,4^{\mathrm{b}} \pm 1,4$ & $25,0^{\mathrm{a}} \pm 1,2$ & $25,9 \pm 1,1$ & $22,5 \pm 1,9$ \\
\hline P3 & $31,2^{\mathrm{b}} \pm 3,5$ & $33,5^{\mathrm{b}} \pm 6,1$ & $29,2 \pm 3$ & $22,5 \pm 3,2$ \\
\hline $\mathrm{P} 4$ & $28,4^{\mathrm{ab}} \pm 1,1$ & $22,7^{\mathrm{a}} \pm 0,5$ & $27,8 \pm 3$ & $19,5 \pm 1,3$ \\
\hline \multicolumn{5}{|l|}{ Konversi ransum } \\
\hline P0 & $4,6^{\mathrm{c}} \pm 0,3$ & $4,6^{\mathrm{a}} \pm 0,5$ & $5,5^{\mathrm{b}} \pm 0,9$ & $8,0^{\mathrm{b}} \pm 1,2$ \\
\hline $\mathrm{P} 1$ & $4,7^{c} \pm 0,1$ & $4,3^{\mathrm{a}} \pm 0,1$ & $4,9^{\mathrm{ab}} \pm 0,5$ & $6,0^{\mathrm{a}} \pm 0,3$ \\
\hline $\mathrm{P} 2$ & $3,7^{\mathrm{a}} \pm 0,1$ & $5,9^{\mathrm{b}} \pm 0,4$ & $6,0^{\mathrm{b}} \pm 0,3$ & $7,4^{\mathrm{b}} \pm 0,6$ \\
\hline P3 & $4,{ }^{3 \mathrm{bc}} \pm 0,5$ & $4,2^{\mathrm{a}} \pm 0.9$ & $4,5^{\mathrm{a}} \pm 0,4$ & $6,2^{\mathrm{a}} \pm 1,1$ \\
\hline $\mathrm{P} 4$ & $4,1^{\mathrm{a}} \pm 0,1$ & $6,3^{c} \pm 0,3$ & $5,7^{\mathrm{b}} \pm 0,7$ & $8,5^{\mathrm{b}} \pm 0,7$ \\
\hline
\end{tabular}

Keterangan: superscript berbeda pada kolom dan variabel yang sama menunjukkan perbedaan nyata $(\mathrm{P}<0,05)$ 
Pertambahan bobot badan (PBB) puyuh dalam penelitian ini masih dalam kisaran normal sesuai dengan yang dilaporkan oleh Florana et al. (2017) bahwa PBB puyuh pada minggu ke-1 hingga minggu ke-5 secara berturut turut adalah (13,1-18,4 $\mathrm{g}),(28,1-33,2 \mathrm{~g}),(39,4-51,4 \mathrm{~g}),(19,2-23,2 \mathrm{~g}),(16,2$ $-22,1 \mathrm{~g})$.

\section{Konversi Ransum}

Penggunaan asam sitrat organik belimbing wuluh memberikan pengaruh nyata $(\mathrm{P}<0,05)$ terhadap konversi ransum. Penggunaan asam organik memiliki konversi lebih rendah pada minggu pertama, tetapi relatif sama pada minggu ketiga dan keempat dibanding kontrol. Penggunaan asam sitrat sintetis nyata dapat menurunkan $(\mathrm{P}<0,05)$ konversi pakan minggu ketiga dan keempat dibanding kontrol dan asam organik belimbing wuluh. Napirah et al. (2019) melaporkan bahwa penggunaan asam sitrat sintetis pada puyuh layer dapat meningkatkan produksi telur dan menekan konversi pakan. Florana et al. (2017) Melaporkan bahwa konversi ransum meningkat seiring bertambahnya umur puyuh.

Penggunaan acidifier dapat menekan konversi ransum dengan cara meningkatkan optimalisasi penyerapan nutrien. Santia et al. (2019) melaporkan bahwa suplementasi asam sitrat dan mikropartikel cangkang telur dapat menigkatkan kecernaan protein ransum dan massa protein daging. Acidifier merupakan asam organik yang bermanfaat dalam preservasi dan memproteksi pakan dari perusakan oleh mikrobia, fungi dan membuat suasana asam dalam usus halus (Pio et al., 2017). Rahmawati et al. (2014), melaporkan bahwa penggunaan asam asetat dalam ransum cenderung membuat penurunan $\mathrm{pH}$ dalam usus halus, semakin tinggi peningkatan asam asetat makin rendah $\mathrm{pH}$ khususnya doudenum dan jejenum sedangkan ileum tidak mengalami penurunan berarti.

Konversi ransum dalam penelitian ini mengalami peningkatan setiap minggunya. Napirah et al. (2018) melaporkan bahwa konversi ransum puyuh fase grower pada minggu ke-3 hingga ke-6 secara berturut turut yaitu $(3,2-4,0),(4,1-5,3),(5,9-$ $7,3)$ dan $(8,3-9,8)$. Konversi pakan puyuh fase grower mengalami peningkatan konversi ransum seiring bertambahnya umur, yang disebabkan oleh penurunan pertambahan bobot badan dan meningkatnya konsumsi pakan.

\section{KESIMPULAN}

Penggunaan asam organik sari belimbing wuluh belum mampu memberikan performa yang lebih baik dibanding kontrol, sedangkan penggunaan asam sitrat sintetis menunjukkan hasil yang lebih efisien dibanding kontrol dan asam organik sari belimbing wuluh.

\section{DAFTAR PUSTAKA}

Byrd, J.A., B.M. Hargis, D.J. Cardwell, R.H. Bailley, K.L. Reynolds, \& R.L. Brewe. 2001. Effect of lactic acid administation in the drinking water during preslaughter feed withdrawl on Salmonella and Campylobacter contamination of broiler. Poultry Science 80:278-283.

Florana, B., E. Dihansih, \& R. Handarini. 2017. Performa puyuh periode starter-grower yang diberi ransum imbuhan mengandung bawang putih (Allium sativum) dan jintan (Cuminum cyminum). Jurnal Peternakan Nusantara 3(2):95-102.

Ghazalah, A.A., A.M. Atta,, K. Elkoub, M.E.L. Moustafa, \& F.H. Shata. 2011. Effect of dietary supplementation of organic acids on performance, nutrients digestibility and health of broiler chicks. International Journal of Poultry Science 10:176-184.

Gunal, M., G. Yayli, O. Kaya, N. Karahan, \& O. Sulak. 2006. The effects of antibiotic growth promoter, Probiotic or organic acid supplementation on performance, intestinal microflora and tissue of broilers. International Journal of Poultry Science 5: 149-155.

Hamed, D.M. \& A.M.A. Hassan. 2013. Acids Supplementation to Drinking Water and Their Effects on Japanese Quails Experimentally Challenged with Salmonella enteritidis. Research in Zoology 3(1):15-22.

Hidayat, K., S. Wibowo, L.A. Sari, \& A. Darmawan. 2018. Acidifier alami air perasaan jeruk nipis (Citrus aurantiun) sebagai pengganti antibiotik growth promotor ayam broiler. Jurnal Ilmu Nutrisi dan Teknologi Pakan 16(2):27-33.

Napirah, A., H. Has, A. Pagala, \& L.O. Nafiu. 2019. Production performance of laying Japanese quail that given citric acid as acidifier. International Conference on Animal Production for Food Sustainability. IOP Conf. Series: Earth and Environmental Science 287 (2019) 012002.

Napirah, A., H. Has, L. O. Nafiu, A. Bain, \& T. Saili. 2018. Imbangan protein dan energi 
berbeda dalam ransum puyuh fase grower terhadap konsumsi pakan, pertambahan bobot badan, dan konversi ransum. Jitro 5(2): 53-57.

Natsir, M.H, O. Sjofjan, A. Manab. \& K.U. Al Awwaly. 2007. Pengaruh penggunaan kombinasi asam sitrat dan asam laktat cair dan terenkapsulasi sebagai aditif pakan terhadap penampilan produksi ayam pedaging. Jurnal Agritek 15(1):1410-413.

Pio, P.O., I.B.K. Ardana, \& P. Suastika. 2017. Efektivitas berbagai dosis asam organik dan anorganik sebagai acidifier terhadap histomorfometri duodenum ayam pedaging. Indonesia Medicus Veterinus 6(1):47-54.

Rahmawati, D.P., Mulyono, \& I. Mangisah. 2014. Pengaruh level protein dan asam asetat dalam ransum terhadap tingkat keasaman $(\mathrm{pH})$ usus halus, laju digesta dan bobot badan akhirayam broiler. Animal Agriculture Journal 3(3):409-416.
Santia, H.E., N. Suthama, \& B. Sukamto. 2019. Pemanfaatan protein pada ayam broiler yang diberi ransum menggunakan kalsium mikropartikel cangkang telur dengan suplementasi asam sitrat. Jurnal Sain Peternakan Indonesia 14(3):252-258.

Veeramani, P., S.T. Selvan, \& K. Viswanathan. 2003. Viswanathan.2004.Effect of acidic and alkaline drinking water on body weight gain and feed efficiency in commercial broiler. International Journal of Poultry Science 38: 42-44.

Youssef, A.A., A. El-Hamid, F. Hany, F. Ellakany, Bovera, M. A. Al-Harthi, \& S.A. Ghazaly. 2013. Growing and laying performance of japanese quail fed diet supplemented with different concentrations of acetic acid, Italian Journal of Animal Science 12(2):222-230. 